\title{
Valorization of Deproteinated Potato Juice Water into $\beta$-Glucan Preparation of $C$. utilis Origin: Comparative Study of Preparations Obtained by Two Isolation Methods
}

\author{
Anna Bzducha-Wróbel ${ }^{1}$ (D) $\cdot$ Piotr Koczoń $^{2} \cdot$ Stanisław Błażejak ${ }^{1} \cdot$ Jakub Kozera $^{1} \cdot$ Marek Kieliszek $^{1}$
}

Received: 16 June 2018 / Accepted: 1 March 2019 / Published online: 20 March 2019

(c) The Author(s) 2019

\begin{abstract}
Purpose $\beta(1,3) /(1,6)$-Glucan of yeast origin is a bioactive polysaccharide used in nutrition, healthcare, agriculture and wastewater treatment. Yeast cultivation focused on the biosynthesis of $\beta$-glucan with simultaneous utilization of industrial wastes as a culture medium is a new way of obtaining these functional polysaccharides. The aim of current study was to isolate and characterize the purified $\beta(1,3) /(1,6)$-glucan preparation from Candida utilis ATTC 9950 biomass propagated in waste deproteinated potato juice water with the addition of glycerol.

Methods The production of biomass of tested C. utilis strain was carried on biofermentor scale. The isolation of cell wall $\beta$-glucan was tested with two different methods: the alkaline-acid procedure coupled with hot-water extraction (method 1) and isolation based on cell wall autoclaving, lipids extraction and proteolysis (method 2). The isolated fractions were further analyzed with infrared spectroscopy.

Results Obtained preparations contained approx. $82 \%$ of $\beta(1,3) /(1,6)$-glucan after shortened extraction comparing with procedures described in literature. Infrared spectra of examined preparations demonstrated highly similar pattern to $\beta$-glucan standard of Saccharomyces cerevisiae origin. The preparation produced by method 2 showed higher ratio of $\beta(1,3)-$ to $\beta(1,6)$-glucan. The production efficiency for method 2 was $70 \%$, while for the method 1 it was significantly lower, i.e. $49 \%$, indicating substantial material losses during alkaline-acid purification.

Conclusions The $C$. utilis ATCC 9950 yeast cultivated on waste deproteinated potato juice water supplemented with glycerol is a highly efficient system to obtain purified $\beta$-glucan preparation.
\end{abstract}

\section{Graphical Abstract}

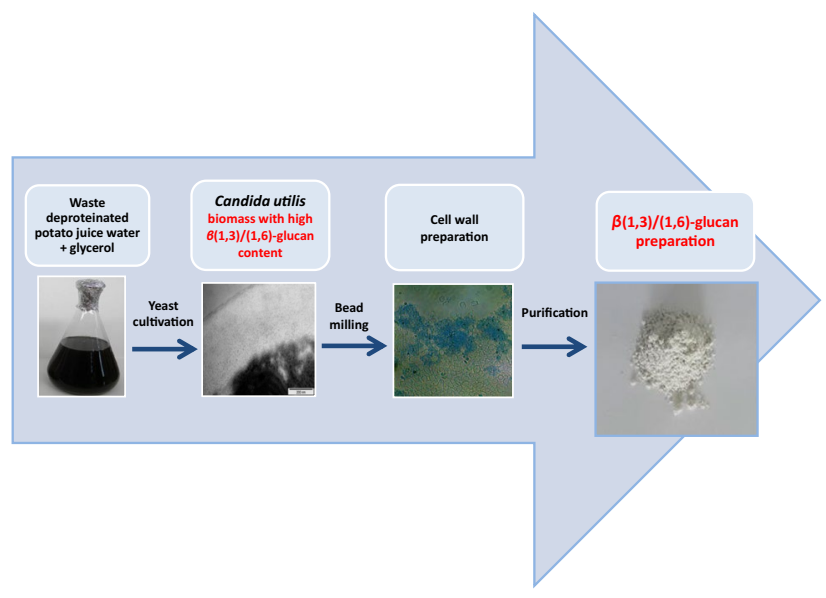

Keywords $\beta(1,3) /(1,6)$-glucan · Candida utilis · Deproteinated potato juice water · Glycerol $\cdot$ Isolation

Extended author information available on the last page of the article 


\section{Statement of Novelty}

Management of substantial quantity of waste deproteinated potato juice water constitutes a problem for the starch industry. Presented results highlight the potential of valorization of the waste during production of high-value $\beta(1,3)$ $(1,6)$-glucan preparation using Candida utilis yeast as the source of this functional polysaccharide. The efficiency of the process of isolation of discussed polymer from C. utilis biomass is high after cultivation in studied substrates. Proposed solution could improve the economics of the production of yeast origin $\beta$-glucan.

Additionally, to the best of our knowledge in the literature there is no data considering isolation and characterization of $\beta$-glucan of $C$. utilis origin and its comparison with extracted from Saccharomyces cerevisiae biomass, the main source of yeast $\beta$-glucan on industrial scale nowadays.

\section{Introduction}

$\beta$-Glucan polymers are biologically active polysaccharides created by $\beta$-D-glucopyranose residues polymerized through $\beta(1,3)-, \beta(1,4)$ - and/or $\beta(1,6)$-glycoside bonds, what depends on the source of glucan origin $[1,2]$. They make up cell walls of microscopic fungi, bacteria, plants, algae and lichen [3].

$\beta(1,3)$-Glucan is the major structural constituent of yeast cell wall [4], while the organelle accounts for approximately $20-30 \%$ of dry weight of the biomass $[4,5]$. Mannoproteins, $\beta(1,6)$-glucan and chitin are also structural polymers of yeast cell wall [6].

Yeast deserves special attention as a source of $\beta$-glucan considering high propagation rate and possible re-modelling of cell wall chemical composition depending on growth conditions [7-10]. Different stress factors can cause the wall structure to be strengthened or thickened through intensified synthesis of constituent polysaccharides $[3,6,7]$.

Extensive studies have been done on glucan characterization of S. cerevisiae and Candida albicans origin, much less is known about glucans synthesized by other fungi $[1,4,11,12]$. To the best of our knowledge, in the literature there is no data considering isolation and analysis of $\beta(1,3)$-glucan preparation purified from the biomass of C. utilis origin using different methods. The species of Candida utilis yeast is recognized as safe because of long history in food additives and feed production and could be a new, efficient $\beta$-glucan source on an industrial scale. Our previous studies stated the important increase in the content of discussed functional polysaccharide in cells of $C$. utilis cultivated on food-agricultural waste-deproteinated potato juice water (DPJW) with the addition of glycerol $[10,13]$. Management of substantial quantity of DPJW constitutes a problem for the potato starch industry [14-16]. The waste arises after deproteinization of potato juice generated through potato tubers disintegration during starch separation. Discussed by-product is also named as deproteinated potato wastewater in literature [15]. According to trends analysis in global potato starch industry the market reached app. $3.6 \mathrm{mln}$ tons in 2017 and the forecast indicate an increase in potato starch production $[15,17]$. In accordance with calculations [15] the global potato starch industry generated app. 10.8 million $\mathrm{m}^{3}$ of deproteinated potato juice water in 2017 and it will be app. 12 million $\mathrm{m}^{3}$ by 2023 .

There have been very interesting applications developed for waste potato juice (fresh or spray-dried) using in healthoriented food products [18]. Discussed functional food products (pâtés, pasta, frankfurters fortified with potato juice) are especially addressed to patients with inflammatory bowel disease [19-21]. The discussed waste was also applied as nitrogen source in yeast lipids biosynthesis [15].

Supplementation of DPJW with glycerol is essential for glucan synthesis and high yeast biomass productivity [13]. The waste glycerol fraction arising from biodiesel production and assimilated as a carbon and energy source by $\mathrm{Can}$ dida yeast species can be used for that purpose.

Functional properties of yeast $\beta$-glucan depend on chemical and physical features of the polysaccharide affected by degree of polymerization, degree of branching and as a result by specific molecular conformation, all arise from yeast genetic characteristic and cultivation conditions [1, 2, $4,5,22]$. Yeast $\beta(1,3) /(1,6)$-glucan can form single or triple helix structure or is arranged in random coil $[1,11]$. The triple helix structure of $\beta(1,3)$-glucan polymer is considered to be important for biological activity of the polysaccharide [1]. Batbayar et al. [1] indicate that $\beta(1,3)$-glucans of larger molecular weight or higher branching degree through $\beta(1,6)$ glycosidic bonds show stronger immunostimulation activity comparing with linear polymers. However, the precise impact of $\beta$-glucan branching degree upon biological activity is rather unclear and unequivocal results of investigation are still missing [23].

Bioactive and other functional properties of yeast origin $\beta(1,3)$-glucan are extensively studied and possible industrial applications of that polysaccharide are well documented. Orally administrated particulated yeast $\beta(1,3)$-glucan modulates innate and adaptive immune response [1,24-27]. Discussed polysaccharide is investigated as oral vaccine carriers [28]. The reduction of cholesterol and lipids level in blood by yeast $\beta$-glucan is indicated [24]. Yeast $\beta(1,3)$-glucan derivatives show antioxidant and anti-lipid peroxidation 
effect by free radicals scavenging properties [29]. Mannan, a by-product generated from cell walls during yeast $\beta$-glucan isolation, is characterized with interesting antioxidant activity also [30]. Different chemical derivatization strategies of discussed polysaccharide can improve its biological compatibility and activity in different biological systems [31]. Preparations of yeast glucan are recommended to be used as feed additives with mycotoxins binding properties also [32]. $\beta$-Glucan isolated from $S$. cerevisiae yeast was authorized as a novel food ingredient in European Union and is used in production of specific food categories, including diet supplements [33]. There are studies on yeast $\beta$-glucan application as edible films and food packaging component [34] as well as food additives of technological significance $[2,27$, 35, 36].

Procedures currently used for yeast $\beta$-glucan isolation and purification were developed and applied for the biomass of $S$. cerevisiae yeast, commonly used as a $\beta$-glucan source for industrial applications. The methods are divided into chemical ones, primarily based on alkaline extraction or possible acid extraction, and enzymatic ones, that vary in relation to proteolytic or lipolytic enzyme preparations and hydrolysis conditions [22, 37-39]. Attempts to improve mentioned methods were based on application of additional stages of purification like hot water extraction or ultrasounds treatment [40-42].

Isolation procedures influence on the structure and molecular weight of $\beta$-glucan [27]. Proper extraction methods need to be applied to preserve the integrity of glucan molecules but also to obtain high $\beta$-glucan yield and purity at the same time. Isolation procedures of yeast $\beta$-glucan based on acid and alkali treatment or a combination of both, may contribute to degradation of the polysaccharide, reduced yields and limited purity [22, 37, 42]. Soft treatments like enzymatic purification, hot water extraction and high-pressure homogenization allow to preserve native structure of the polysaccharide [37]. They are very effective in purification, less harmful to the environment and can be easily scaled-up to an industrial process [22, 37]. Hovewer, chemical procedures based on acid and alkali extraction steps are rather less expensive comparing with enzymatic ones.

Yeast species and culture parameters have considerable impact on the efficiency of yeast $\beta$-glucan purification due to differences in cell wall structure and consequently its susceptibility to disruption [22,43-45]. There is no data available in respect of effectiveness of those procedures in relation to yeast other than brewer's and baker's species. Consistently, the aim of the study was to obtain and characterize the $\beta(1,3) /(1,6)$-glucan preparation of Candida utilis ATTC 9950 using two different methods of isolation from the biomass cultivated under conditions intensified the $\beta(1,3) /(1,6)$-glucan synthesis with simultaneous valorization of agro-waste as cultivation medium. For $\beta$-glucan isolation the alkaline-acid extraction procedure coupled with removal of ingredients soluble under autoclaving conditions (method 1) as well as the process based on impurities solubilization under hot-water conditions, lipids extraction using organic dissolvent and enzymatic digestion of proteins (method 2) were applied. The chemical composition and production efficiencies of the preparations were compared in relation to applied methods of purification.

Presented results are useful to the industrial production of yeast origin $\beta$-glucan preparations. We propose the $C$. utilis ATCC 9950 yeast cultivated on waste DPJW supplemented with glycerol as a efficient source of highly purified $\beta$-glucan preparation on industrial scale.

\section{Materials and Methods}

\section{Yeast Strain}

The Candida utilis ATCC 9950 yeast strain from the collection of pure cultures of the Division of Biotechnology and Food Microbiology, Warsaw University of Life Sciences was used as a $\beta(1,3) /(1,6)$-glucan source. Yeast culture was stored on YPD slants at the temperature of $6-8{ }^{\circ} \mathrm{C}$.

\section{Cultivation Medium}

For the purpose of $C$. utilis yeast cultivation, the growth medium was based on waste DPJW (pH 5.0 \pm 0.2 ) supplemented with $10 \%$ of glycerol. The medium facilitates the synthesis of $\beta(1,3) /(1,6)$-glucan in cell walls of studied $C$. utilis ATCC 9950 strain. DPJW was obtained from the processing line of company producing potato starch (Mazovia region, Poland). The medium was sterilized at $121{ }^{\circ} \mathrm{C} / 0.1 \mathrm{MPa} / 20 \mathrm{~min}$ (HICLAVE HG80 autoclave, HMC Europe) and characterized according to BzduchaWróbel et al. [13] considering the content of dry matter, total organic carbon (TOC), total nitrogen content, total sugars and directly reducing sugars. Contents of selected elements in DPJW were determined also (K, S, P, Na, Ca, Mg, Mn) by ICP technique in atomic emission spectrometer (ICP-AES Thermo iCAP 6500 DUO). Obtained results were stated in grams per $1 \mathrm{~L}$ of the medium and presented in Table 1.

\section{Inoculum}

Yeast cells inoculum was prepared in YPD medium $\left(80 \mathrm{~cm}^{3}\right)$ in flasks with capacity of $500 \mathrm{~cm}^{3}$. Cultures were inoculated with cells collected from the slants. The culture was incubated at $28^{\circ} \mathrm{C}$ during about $20 \mathrm{~h}$ with shaking (200 cycles/ min, SM-30 Control). The yeast biomass was centrifugated $\left(15,500 \mathrm{~g} / 4{ }^{\circ} \mathrm{C} / 10 \mathrm{~min}\right.$, Eppendorf 5810R Centrifuge) and rinsed twice with sterile water before suspention in $300 \mathrm{~cm}^{3}$ 
Table 1 Chemical composition of deproteinated potato juice water used for yeast cultivation

\begin{tabular}{lc}
\hline Ingredient & {$\left[\mathrm{g} / \mathrm{dm}^{3}\right]$} \\
\hline Dry matter & $51.9 \pm 0.3$ \\
Total organic carbon & $22.9 \pm 0.8$ \\
Total sugars & $17.0 \pm 0.1$ \\
Directly reducing sugars & $16.4 \pm 0.1$ \\
Nitrogen & $2.0 \pm 0.1$ \\
Protein & $12.5 \pm 0.1$ \\
Phosphorus & $0.29 \pm 0.01$ \\
Potassium & $4.1 \pm 0.4$ \\
Sulphur & $12.7 \pm 2.1$ \\
Sodium & $0.73 \pm 0.04$ \\
Calcium & $1.27 \pm 0.2$ \\
Magnesium & $0.27 \pm 0.02$ \\
\hline
\end{tabular}

of waste potato juice water. The inoculum received in this way was used for yeast cultivation in biofermentor system.

\section{Cultivation Conditions in Biofermentor}

The biomass of studied Candida utilis yeast was cultivated in 5-L fermentor (BIOFLO 3000, New Brunswick, USA) with a work volume of $3 \mathrm{~L}$ of cultivation medium inoculated with $10 \%(\mathrm{v} / \mathrm{v})$ of inoclum. The impeller rotation speed was $200 \mathrm{rev} / \mathrm{min}$, temperature was set at $28{ }^{\circ} \mathrm{C}$ and airflow at $2.5 \mathrm{v} / \mathrm{v} / \mathrm{min}$. The $\mathrm{pH}$ of culture was not kept constant. The cultivation time was $72 \mathrm{~h}$. Three independent cultivations were performed.

\section{Cell Wall Preparations}

Cell wall preparations were produced by mechanical disintegration of yeast biomass in Bead-Beater GB26 (Biospec Products) bead mill following the procedure described by Bzducha-Wróbel et al. [13]. The material obtained in that way constituted unpurified cell walls that were used for $\beta(1,3) /(1,6)$-glucan isolation based on methods described in "Isolation of $\beta(1,3) /(1,6)$-glucan preparations" section.

\section{Isolation of $\beta(1,3) /(1,6)$-Glucan Preparations}

\section{Method 1: Alkaline-Acid Isolation Coupled with Hot-Water Extraction by Autoclaving}

The first of the applied procedures of $\beta(1,3) /(1,6)$-glucan purification of $C$. utilis origin was based on the method described by Zechner-Krpan et al. [2] with modifications. Briefly, approximately $1000 \mathrm{mg}$ of unpurified cell wall preparations was weighed and subsequently undergo alkali extraction. For that purpose $20 \%$ suspended matter was prepared in $1 \mathrm{M} \mathrm{NaOH}$. Samples prepared in that way were incubated in the water bath $\left(90^{\circ} \mathrm{C} / 1 \mathrm{~h}\right)$. After incubation all samples were centrifuged $\left(4600 \mathrm{~g} / 4{ }^{\circ} \mathrm{C} / 10 \mathrm{~min}\right)$, supernatants were poured out, and the specimens were rinsed with deionised water three times, centrifuging each time. The output specimens were suspended in $1 \mathrm{M}$ solution of acetic acid (Avantor Performance Materials, Poland). The suspended matters were incubated in the ambient temperature for $2 \mathrm{~h}$. After that all samples were centrifuged, rinsed in water and centrifugated again. The output specimens were used for preparing $20 \%$ suspended matter in $0.1 \mathrm{M}$ sodium citrate buffer. The samples underwent autoclaving $\left(121{ }^{\circ} \mathrm{C} / 0.1 \mathrm{MPa} / 1 \mathrm{~h}\right)$ and were centrifuged. The output specimens were rinsed in distilled water three times, centrifuged every single time, and later dried by means of hot air inflow $\left(80{ }^{\circ} \mathrm{C} / 24 \mathrm{~h}\right.$ ). Dried $\beta$-glucan preparations were milled in laboratory mill and were characterised according to point "Characterisation of cell wall and $\beta(1,3) /(1,6)$-glucan preparations" of the methodology.

\section{Method 2: Hot-Water Extraction Coupled with Dissolution of Lipids by Organic Solvent and Enzymatic Protein Digestion}

The second method applied for C.utilis $\beta(1,3) /(1,6)$-glucan isolation and purification was developed on the basis of procedures recommended by Freimund et al. [22] and Magnani et al. [42] with modifications. Approximately $1000 \mathrm{mg}$ of cell wall preparations were weighed and suspended in $0.02 \mathrm{M}$ sodium potassium buffer, pH 7.5 (Avantor Performance Materials, Poland). Zirconium-glass beads of $1 \mathrm{~mm}$ in diameter were added and samples were autoclaved $\left(121{ }^{\circ} \mathrm{C} / 0.1 \mathrm{MPa} / 1 \mathrm{~h}\right)$. Next, all samples were centrifuged $\left(4600 \mathrm{~g} / 4{ }^{\circ} \mathrm{C} / 10 \mathrm{~min}\right.$ ) and obtained specimens were rinsed with water three times, centrifuged each time under conditions mentioned above. Next $3 \mathrm{~cm}^{3}$ of isopropyl alcohol was added to specimens (Avantor Performance Materials, Poland) and samples were incubated in water bath $\left(60^{\circ} \mathrm{C} / 2 \mathrm{~h}\right)$. Supernatants were poured out while specimens were rinsed in deionized water three times. The enzymatic digestion of proteins present in specimens of cell walls preparations was aided by Pronase E enzyme (Sigma-Aldrich, USA) using $200 \mathrm{ng} / \mathrm{cm}^{3}$ solution prepared in $0.01 \mathrm{M}$ potassium phosphate buffer ( $\mathrm{pH} 7.0)$ with the addition of $5 \mathrm{mg} /$ $\mathrm{cm}^{3}$ of sodium lauryl sulfate (Avantor Performance Materials, Poland). The sludges of purified preparations were suspended in $9.5 \mathrm{~cm}^{3}$ of enzyme solution. Samples were incubated at $37{ }^{\circ} \mathrm{C}$ for approximately $20 \mathrm{~h}$. After enzymatic hydrolysis, specimens were rinsed in water three times, centrifuged and dried by means of hot air inflow $\left(80^{\circ} \mathrm{C} / 24 \mathrm{~h}\right)$. Obtained purified $\beta$-glucan preparation were milled and characterised in compliance with point "Characterisation 
of cell wall and $\beta(1,3) /(1,6)$-glucan preparations" of the methodology.

\section{Characterisation of Cell Wall and $\beta(1,3) /$ $(1,6)$-Glucan Preparations}

\section{FT-IR Spectra of Purified $\beta$-Glucan Preparations}

For all samples of $\beta$-glucans obtained IR spectra were registered in the middle range i.e. $4000-400 \mathrm{~cm}^{-1}$. The procedure was carried according to the method [24] with little modifications. For fine powder preparation approx. $1 \mathrm{mg}$ of $\beta$-glucan was mixed with approx. $3 \mathrm{~g}$ of solid $\mathrm{KBr}$ and grounded in laboratory mill Specamill. The powder sample was pressed into transparent tablet by applying 5 tons of pressure using hydraulic piston. Ready pallet was placed in holder which in turn was placed in measuring chamber rails. Spectra were registered as ratio of spectrum of given sample to spectrum of background that was registered without sample in measuring chamber to eliminate the effect of water vapor and carbon dioxide. Instrument System 2000 was operated by GRAMS software. FT-IR spectra were recorded with the resolution of $4 \mathrm{~cm}^{-1}$ and ten scan.

\section{Protein Content}

Total nitrogen content in the analyzed samples of cell walls and $\beta$-glucan preparations were determined with the Kjeldahl method (Büchi mineralization and distillation units, Büchi Labourtechnik, Flawil, Switzeland) according to [46]. Nitrogen content was expressed per crude proteins using a conversion factor of 6.25. It was assumed that all nitrogen comes from proteins only.

\section{Lipids Content and Fatty Acids Composition}

The analysis was performed according to [47]. The lipid content was expressed as a sum of individual fatty acids content detected in analysed preparations of yeast cell wall and purified $\beta$-glucan samples using chromatography equipped with a flame ionization detector (GC-FID, TRACE ${ }^{\mathrm{TM}} 1300$, Thermo Scientific, USA). Fatty acids contents were calculated on the basis of internal standard addition and taking into account the correction factors determined for each fatty acids. App. $100 \mathrm{mg}$ of dry preparations were mixed with $1 \mathrm{~cm}^{3}$ of hexane and $0.2 \mathrm{~cm}^{3}$ of internal standard (triacyloglicerole of $\mathrm{C} 21: 0$ at $5 \mathrm{mg} / \mathrm{cm}^{3}$ ). Next, $0.7 \mathrm{~cm}^{3}$ of $8 \mathrm{M}$ $\mathrm{KOH}$ and $3.3 \mathrm{~cm}^{3}$ of methanol were added. Samples were incubated at $55^{\circ} \mathrm{C}$ for $1.5 \mathrm{~h}$ with shaking. After cooling $0.58 \mathrm{~cm}^{3} 12 \mathrm{M} \mathrm{H}_{2} \mathrm{SO}_{4}$ was added and samples were incubated at $55{ }^{\circ} \mathrm{C}$ for additional $1.5 \mathrm{~h}$ with shaking. After cooling, $2 \mathrm{~cm}^{3}$ of hexane were added to each sample and the hexane phases were analysed by GC-FID. Separation of fatty acid methyl esters was performed using an RTX-2330 capillary column $(60 \mathrm{~m} \times 0.25 \mathrm{~mm} \times 0.2 \mu \mathrm{m}$, Restek, USA). The oven temperature was set at $50{ }^{\circ} \mathrm{C}(3 \mathrm{~min})$, a temperature increase rate was $3^{\circ} \mathrm{C} / \mathrm{min}$ up to $250^{\circ} \mathrm{C}(5 \mathrm{~min})$. Nitrogen $\left(1.6 \mathrm{~cm}^{3} / \mathrm{min}\right)$ was the carrier gas. The temperatures of the injector and detector were set at 230 and $260{ }^{\circ} \mathrm{C}$, respectively. Identification of individual fatty acids was performed on the basis of retention times of Nu-Chek-Prep Inc. (USA) external reference standards present in GLC 461 solution (32 fatty acids methyl esters from $\mathrm{C} 4: 0$ to $\mathrm{C} 24: 0)$.

\section{The Content of Total Sugars and $\beta(1,3)$ $(1,6)$-Glucan}

The content of total sugars, as reducing sugars expressed per glucose, was determined by the colorimetric method with DNS at the wavelength of $540 \mathrm{~nm}$ (BIO-RAD SmartSpec 3000) according to [46]. Cell wall preparations (app. $20 \mathrm{mg})$ were subjected to acid hydrolysis $\left(72 \% \mathrm{H}_{2} \mathrm{SO}_{4}\right.$, $95{ }^{\circ} \mathrm{C} / 4 \mathrm{~h}$ ) in water bath (Memmert WNB14, Germany) before reducing sugars determination. The content of sugars was calculated using a standard curve prepared for glucose $\left(\mathrm{y}=2.3279 \mathrm{x}-0.0755, \mathrm{R}^{2}=0.9989\right)$.

The total content of $\beta(1,3)(1,6)$-glucan was determined according to [46] using an Enzymatic Yeast Beta-Glucan Kit by Megazyme (K-EBHLG 03/13) following procedure recommended by the producer. The UV-1800 UV/VIS, RAYLEIGH spectrophotometer was used.

\section{The Content of Alkali Soluble and Alkali Insoluble Polysaccharides Fractions}

Purified $\beta(1,3) /(1,6)$-glucan preparations were characterised in terms of the content of alkali soluble and alkali insoluble polysaccharides fractions [10, 48]. Approximately $20 \mathrm{mg}$ of purified $\beta$-glucan preparations were taken. Next $1.5 \mathrm{~cm}^{3}$ of $3 \% \mathrm{NaOH}$ was added in order to run the first cycle of alkaline extraction in the water bath $\left(75^{\circ} \mathrm{C} / 1 \mathrm{~h}\right)$. Subsequent samples were centrifuged $(3900 \mathrm{~g} / 10 \mathrm{~min})$ and supernatants were collected. Additional $1.5 \mathrm{~cm}^{3}$ of $\mathrm{NaOH}$ portion was added to each specimens obtained after first extraction step and samples were incubated under conditions as described above. After incubation samples were centrifuged and the obtained supernatants were mixed with the alkali soluble fraction collected after the first step of extraction. The last cycle of extraction was performed using $2.0 \mathrm{~cm}^{3}$ of $\mathrm{NaOH}$ added to each specimens. Finally, supernatants derived from three subsequent stages of alkaline extraction of a given sample were combined. And analyzed in terms of the total content of polysaccharides soluble in alkali (soluble $\beta(1,3) /$ $(1,6)$-glucan fractions, mannoproteins, $\alpha$-glucan). For that 
purpose all samples were subjected to acid hydrolysis and total sugars content in compliance with point "The content of total sugars and $\beta(1,3)(1,6)$-glucan" of the methodology.

The specimens derived by alkaline extraction contain yeast $\beta(1,3)$ - and $\beta(1,6)$-glucan fractions insoluble in alkali-the main $\beta$-glucans type present in yeast cell wall. The total content of alkali insoluble $\beta$-glucans was determined by means of total sugars analysis by colorimetric method with DNS after acid hydrolysis of specimens (described above). At the same time specimens of polysaccharides insoluble in alkali (parallel extractions) were subjected to enzymatic hydrolysis using Zymolyase 20T preparation according to point "The content of $\beta(1,3)$ - and $\beta(1,6)$-glucan insoluble in alkali" of the methodology.

\section{The Content of $\beta(1,3)$ - and $\beta(1,6)$-Glucan Insoluble in Alkali}

Speciments of $\beta$-glucan fractions insoluble in alkali were subjected to enzymatic digestion using Zymolyase 20T preparation (MP Biomedicals LLC) [10, 48]. The preparation consist with $\beta(1,3)$-glucan laminaripentaohydrolase, $\beta(1,3)$-glucanase, protease, mannanase, amylase, xylanase and phosphatase. The glucose polymers are hydrolyzed at the $\beta(1,3)$-glucan linkages with laminaripentaose as the principal product while $\beta(1,6)$-glucan is not subject to digestion. The purpose of this stage was to define the content of alkali insoluble $\beta(1,3)$ - and $\beta(1,6)$-glucan indyvidually. The content of $\beta(1,3)$-glucan was calculated as difference between the total content of sugars present in the alkali insoluble specimen derived after alkali extraction and total content of $\beta(1,6)$-glucan (sum of sugars analysed in specimen derived by zymolyase hydrolysis of alkali insoluble fraction plus sugars analysed in samples dialysates of after enzyme digestion). It was assumed that alkali insoluble specimens not to contain chitin.

Alkali insoluble specimens were rinsed with $0.1 \mathrm{M}$ Tris-HCl buffer ( $\mathrm{pH} 7.4$ ) twice and then centrifuged $(3214 \mathrm{~g} / 15 \mathrm{~min})$. Next $1.5 \mathrm{~cm}^{3}$ of zymolyase preparation $\left(5 \mathrm{mg} / \mathrm{cm}^{3}\right)$ dissolved in $0.01 \mathrm{M}$ Tris-HCl buffer ( $\left.\mathrm{pH} 8.0\right)$ was added to each sample. Samples were incubated approx. $20 \mathrm{~h}$ in water bath with shaking and at the temperature of $37^{\circ} \mathrm{C}$.

After hydrolysis samples were centrifuged (3214 g/15 min). Obtained specimens contained $\beta(1,6)$ glucan fractions not digested by the enzyme. The content of $\beta(1,6)$-glucan was estimated as total sugars by colorimetric method with DNS after acid hydrolysis of specimens.

The content of $\beta(1,6)$-glucan was also defined in dialysates of supernatants derived after zymolyase digestion of specimens insoluble in alkali. Dialysis was conducted in order to separate fractions of hydrolysed $\beta(1,3)$-glucan from non-hydrolysed $\beta(1,6)$-glucan remained in dialysates.
Dialysis was carried out using high retention cellulose tubing bags (Sigma-Aldrich, St. Louis, USA) submerged in deionised water for $24 \mathrm{~h}$. Samples were placed on the magnetic stirrer (ES 24, WIGO, Poland). Next, dialysates were subjected to acid hydrolysis and total sugars were determined according to methodology described above.

\section{Production Efficiency of $\beta$-Glucan Preparations in Relation to Purification Method}

Production efficiencies (PE) of $\beta$-glucan preparations in terms of the method 1 and 2 were defined according to the following formula:

PE [\%] $=\left(\mathrm{m}_{\mathrm{CW}}-\mathrm{m}_{\beta-\mathrm{G}}\right) \times 100 / \mathrm{m}_{\mathrm{CW}}$, where $\mathrm{m}_{\mathrm{CW}}$ was a weight of cell wall preparation subjected to purification while $\mathrm{m}_{\beta-\mathrm{G}}$ was a weight of purified $\beta$-glucan preparation obtained by each studied method of purification in three independent experiments.

\section{Statistical Analysis}

Averages were calculated on a basis of results obtained in three independent experiments (at least). All analysis of tested samples were performed at least in triplicate. Obtained results were subjected to a statistical analysis using the STATISTICA V.13.1 programme.

An analysis with the ANOVA method (Tuckey's test) was carried out at the $\alpha=0.05$ level of significance.

\section{Results and Discussion}

\section{The Analysis of IR Spectra of Studied Preparations}

Obtained preparations of $\beta(1,3) /(1,6)$-glucan isolated from biomass of studied $C$. utilis strain were characterized by infrared spectroscopy. Registered infrared (IR) spectra were analyzed and compared to each other (preparations isolated by methods 1 and 2) in terms of wavenumbers and intensities of bands occurring in studied samples. The spectra were also related to spectrum registered for $\beta(1,3) /(1,6)$-glucan standard of Sacharomyces cerevisiae origin purchased from Sigma company. All similarities and differences were further related to spectral data provided in the literature $[2,24,34$, $42,45,49,50]$. Figure 1 presents three spectra i.e. preparation obtained by alkali-acid isolation coupled with hot-water extraction-method 1 (solid line), preparation purified using hot-water extraction coupled with lipids solubilisation and protein enzymatic hydrolysis-method 2 (dotted line) and standard (dash line). All spectra look quite similarly overall. Wide intense band, very characteristic for $\mathrm{O}-\mathrm{H}$ vibrations, occurs at $3417 \mathrm{~cm}^{-1}$ in all spectra as yeast cell wall is predominantly composed of carbohydrates. 


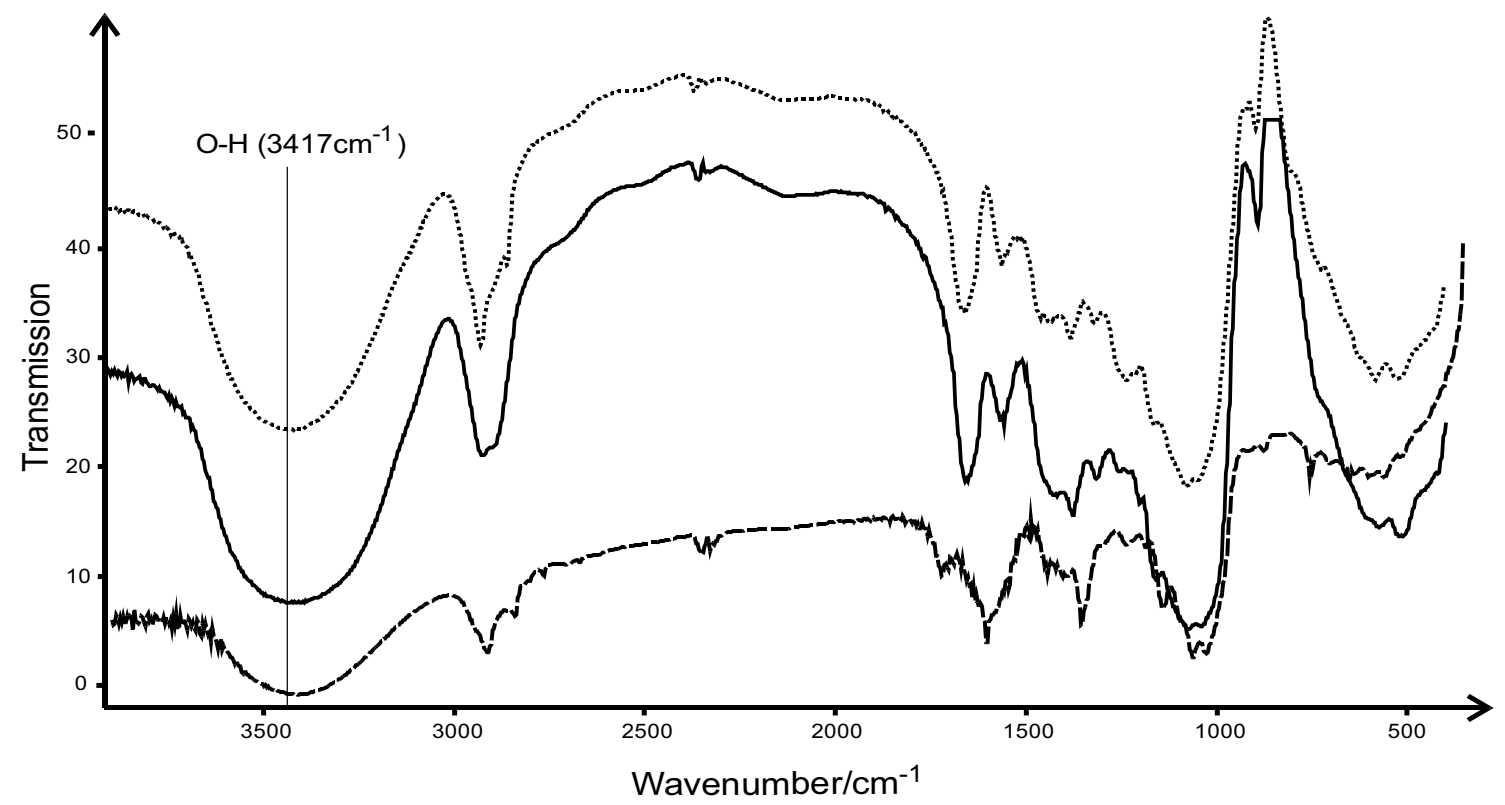

Fig. 1 Infrared spectra of $\beta(1,3) /(1,6)$-glucan isolated from $C$. utilis using method 1 (solid) and method 2 (dotted) and $\beta(1,3) /(1,6)$-glucan standard of S. cerevisiae origin (98\% pure) purchased from Sigma company (dashed) in the range $4000-400 \mathrm{~cm}^{-1}$

For further detailed analysis spectral range (4000-400 $\mathrm{cm}^{-1}$ ) was divided into three specific regions i.e. $3200-2700 \mathrm{~cm}^{-1}, 2000-1450 \mathrm{~cm}^{-1}$ and
$1450-400 \mathrm{~cm}^{-1}$. Listed spectral ranges are presented on Figs. 2, 3 and 4, respectively.

In high spectra region five distinct bands are observed (Fig. 2). They are generated by $\mathrm{C}-\mathrm{H}$ stretches and as located

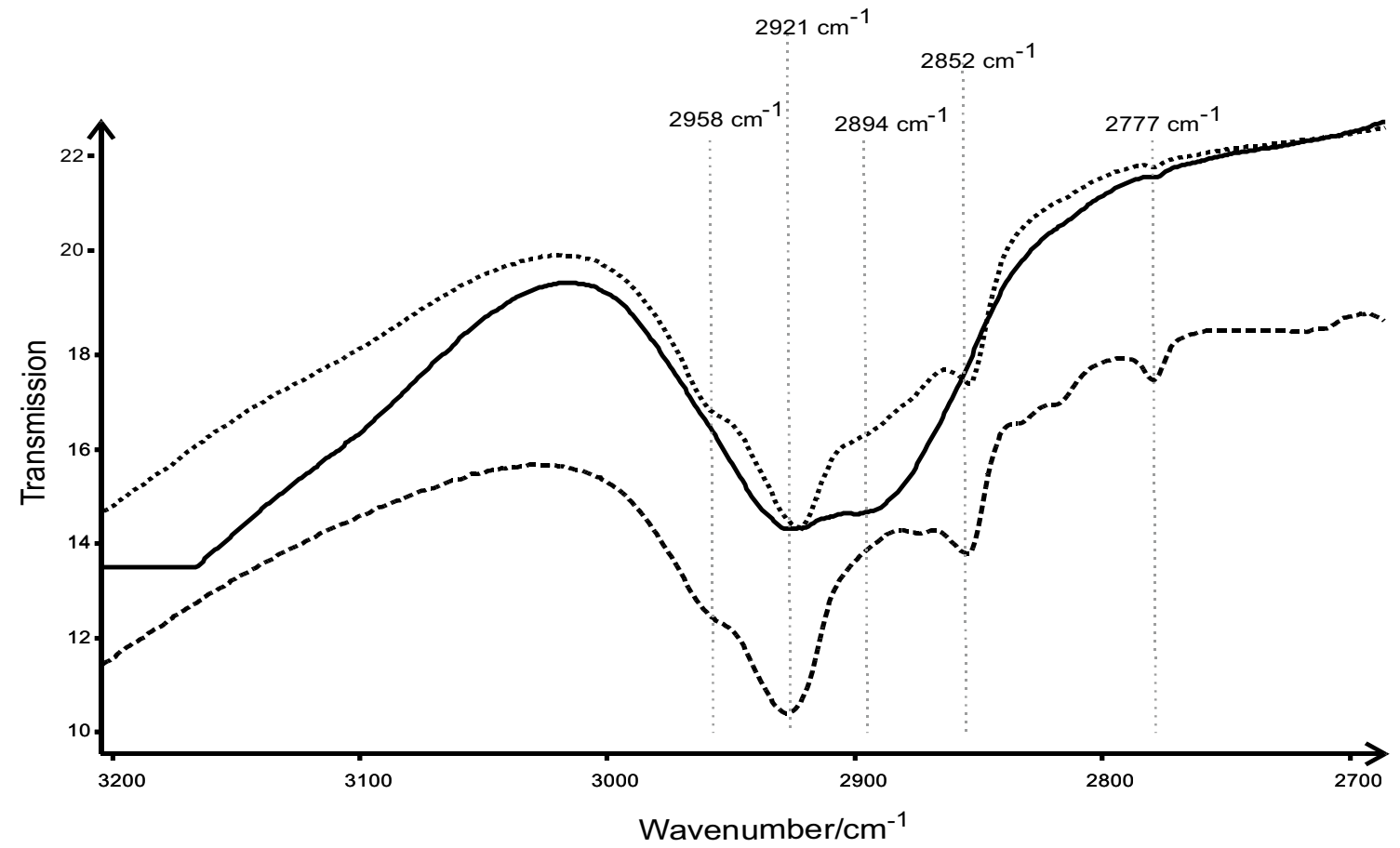

Fig. 2 Infrared spectra of $\beta(1,3) /(1,6)$-glucan isolated from $C$. utilis using method 1 (solid) and method 2 (dotted) and $\beta(1,3) /(1,6)$-glucan standard of $S$. cerevisiae origin ( $98 \%$ pure) purchased from Sigma company (dashed) in the range $3200-2700 \mathrm{~cm}^{-1}$ 


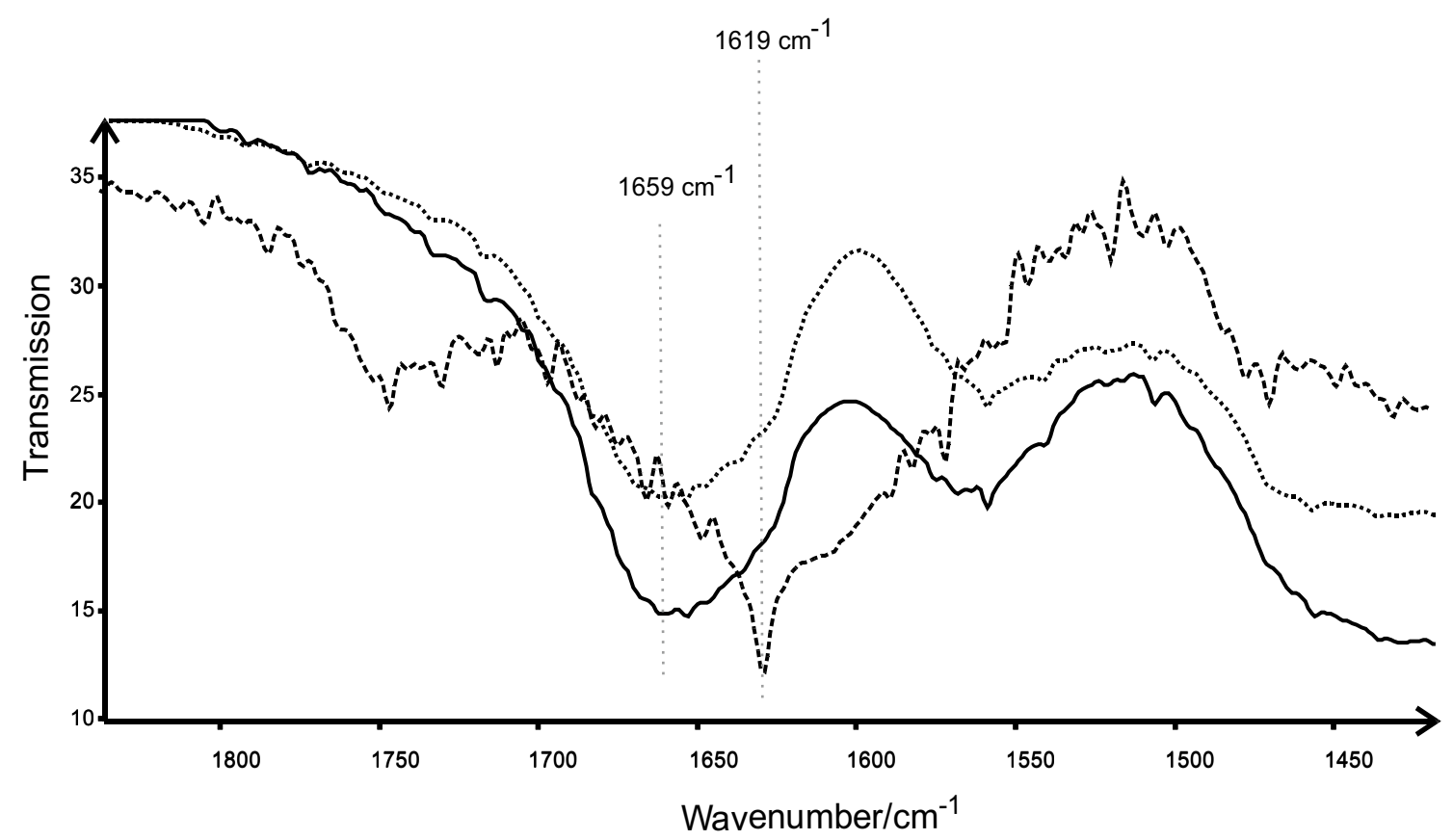

Fig. 3 Infrared spectra of $\beta(1,3) /(1,6)$-glucan isolated from C. utilis using method 1 (solid) and method 2 (dotted) and $\beta(1,3) /(1,6)$-glucan standard of $S$. cerevisiae origin ( $98 \%$ pure) purchased from Sigma company (dashed) in the range $2000-1450 \mathrm{~cm}^{-1}$

below $3000 \mathrm{~cm}^{-1}$ they can only be related to hydrogencarbon chain stretches. Three bands occur in spectra of all samples i.e. 2958, 2921 and $2777 \mathrm{~cm}^{-1}$. Band at $2984 \mathrm{~cm}-1$ is present exclusively in samples obtained in current investigation, while at $2852 \mathrm{~cm}^{-1}$ is present in standard and sample purified with the method 2 . This differentiate three samples, and makes alkali-acid obtained one (method 1 ) with distinct intense band at $2894 \mathrm{~cm}^{-1}$ different. Spectrum of sample purified using the method 2 contain a very weak band at this wave number while standard sample does not have it. This make samples obtained in current experiment similar to each other and slightly different from standard. It can be due to presence of additional $\mathrm{C}-\mathrm{H}$ group as compared to standard or different chemical environment of vibrating group (e.g. impurities influencing it).

Spectral range of $2000-1450 \mathrm{~cm}^{-1}$ is presented on Fig. 3 . Two distinct bands at $1659 \mathrm{~cm}^{-1}$ occur for samples of both preparations, purified by methods 1 and 2 , obtained in current investigation. This band is however absent in standard spectrum which makes spectra different. Additionally standard spectrum has band at $1619 \mathrm{~cm}^{-1}$ that is absent in spectra of samples obtained in current studies. Bands at $1659 \mathrm{~cm}^{-1}$ are quite wide and intense that makes suggestion for them to be generated by $\mathrm{C}=\mathrm{O}$ stretching vibration. This group is however absent in standard of yeast $\beta$-glucan that suggest presence of some impurities e.g. fatty acids, fats, ketons or amides, as all contain $\mathrm{C}=\mathrm{O}$ group. According to literature, bands generated by this group from esters (fats) and carboxylic acids are located in the range of 1600-1650 and $1730-1770 \mathrm{~cm}^{-1}$, respectively. On the other hand, ketons or aldehydes (both aliphatic and aromatic) $\mathrm{C}=\mathrm{O}$ bonds occurs as bands at $1675-1700 \mathrm{~cm}^{-1}$, while $\mathrm{C}=\mathrm{O}$ bond present in amides presents itself at the range of $1630-1700 \mathrm{~cm}^{-1}$. It suggests that bands observed in current investigations are generated by amides (proteins) impurities. Although proteins surely generate another than $\mathrm{C}=\mathrm{O}$ bands they are much less intense and therefore not observed or observed as very weak bands weakly interfering with other characteristic for main component i.e. glucan bands.

The third region selected for analysis was $1450-400 \mathrm{~cm}^{-1}$. This is known as fingerprint region. Spectra from this region are presented on Fig. 4 . There are 9 bands present at 1379/1371, 1315, 1254, 1204, 1159, 1110, 1080, 1043 and 893, respectively. Except bands listed as 1379/1371 and $1110 \mathrm{~cm}^{-1}$ all bands occur in the same location for all samples studied. This suggest the same bonds vibrating in all studied samples generating same bands. Absolute intensities of bands vary, however the ratios of neighboring/selected bands are considered when compounds are identified. According to literature data $[42,45,49,50]$ ratios of following bands 1040/998; 1040/1080; 1135/1080; 1650/891; $1375 / 891$ and $841 / 891$ can serve as purity detectors. The characteristic bands for $\beta(1,3)$ - and/or $\beta(1,6)$-linked glucans are at approx. 1160, 1078, 1041, and $889 \mathrm{~cm}^{-1}$ [49]. Bacha et al. [24] explain that band at app. $1080 \mathrm{~cm}^{-1}$ is due to COC glycosidic bonds with cyclic structure, while 


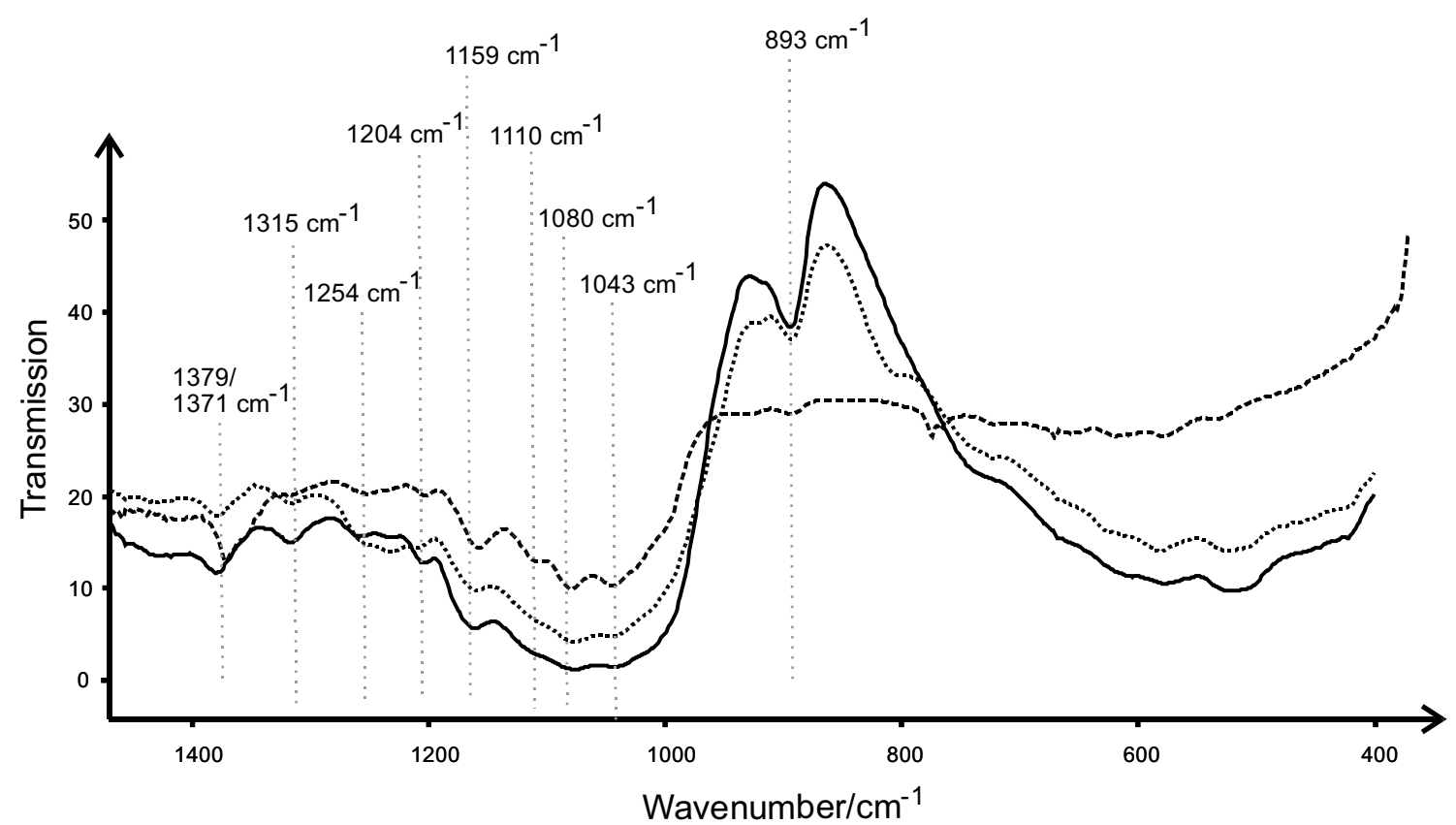

Fig. 4 Infrared spectra of $\beta(1,3) /(1,6)$-glucan isolated from C. utilis using method 1 (solid) and method 2 (dotted) purified and $\beta(1,3) /(1,6)$-glucan standard of S. cerevisiae origin ( $98 \%$ pure) purchased from Sigma company (dashed) in the range $1450-400 \mathrm{~cm}^{-1}$

Table 2 The ratios of intensities of selected bands based on intensity of single bands occuring in spectra of $\beta(1,3) /(1,6)$-glucans isolated from $C$. utilis using the methods 1 and 2

\begin{tabular}{lllll}
\hline Preparation & \multicolumn{4}{l}{ The ratio of selected bands [unitless] } \\
\cline { 2 - 5 } & $1379 / 1080$ & $1659 / 893$ & $1379 / 893$ & $1080 / 893$ \\
\hline$\beta-\mathrm{G}-1$ & 0.65 & 2.07 & 0.24 & 0.37 \\
$\beta-\mathrm{G}-2$ & 0.41 & 3.81 & 0.40 & 0.95 \\
Standard & 0.62 & 0 & 5.62 & 9.04 \\
\hline
\end{tabular}

Single band intensity was measured as area under given bands: 1379/1080; 1659/893, 1379/893, 1080/893

$\beta$ - $G-1$ preparation $\beta(1,3) /(1,6)$-glucan obtained by method $1, \beta-G-2$ preparation of $\beta(1,3) /(1,6)$-glucan obtained by method 2

band around $1040 \mathrm{~cm}^{-1}$ represents $\mathrm{CO}$ bond and is characteristic for carbohydrate composed structure. Signal at app. $890 \mathrm{~cm}^{-1}$ is related to $\beta$-glycosidic anomeric groups. In current studies bands are shifted as compared to literature data therefore following ratios of bands intensities have been considered: 1379/1080; 1659/893; 1379/893 and 1080/893. Data obtained are presented in Table 2. Especially interesting is the ratio of 1659/893 which indirectly informs about protein contamination $[2,24,49]$, as compared to standard that spectrum does not contain band at $1659 \mathrm{~cm}^{-1}$ at all. This ratio is zero for standard while 3.81 and 2.07 for preparations obtained by methods 2 and 1 , respectively.

As the ratio of protein/glucan bands (1659/893) is bigger for preparations obtained by the method 2 it suggest alkali-acid purified glucan is less contaminated with proteins. The standard and currently obtained glucans differ in intensities ratios especially in the case of 1379/893 and $1080 / 893$. This is mainly due to very weak band observed for standard at $893 \mathrm{~cm}^{-1}$. Considering chitin, and presuming that band at 1379 is sensitive to $\mathrm{N}$-acetylglucosamine level $[34,40,42,45,49,50]$ one can conclude that standard and glucan purified with alkali-acid method are of the same quality while isolated by the method 2 has smaller content of chitin. In the case of chitin, the quantitative analysis was not conducted in current investigation, which makes it difficult to define the purity of produced $\beta$-glucan preparations unequivocally.

\section{Chemical Composition of Studied Preparations}

\section{Cell Wall Preparations}

Cell wall preparations of investigated $C$. utilis strain were produced through mechanical disintegration of yeast biomass using bead milling. The method preserves the native structure of $\beta$-glucan and can be implemented at industrial scale $[4,46]$. Cell wall preparations were then used as starting material in the process of $\beta$-glucan isolation. Applied procedure of yeast disruption allowed to produce cell wall preparations consist with approx. $73 \mathrm{~g}$ of sugars and approx. $63 \mathrm{~g}$ of $\beta$-glucan in $100 \mathrm{~g}_{\text {d.w }}$. of preparation (Table 3). The protein content was about $16 \mathrm{~g} / 100 \mathrm{~g}_{\text {d.w. }}$ of the preparation. Lipids concentration was only below $0.3 \%$ what could result 
Table 3 Comparison of the chemical composition of $C$. utilis yeast cell wall preparations and $\beta(1,3) /$ $(1,6)$-glucan preparations in relation to purification method

\begin{tabular}{llllll}
\hline Preparation & $\begin{array}{l}\text { Total sugars } \\
{\left[\mathrm{g} / 100 \mathrm{~g}_{\text {d.w. }} \text { prepa- }\right.} \\
\text { ration] }\end{array}$ & $\begin{array}{l}\beta(1,3) /(1,6) \text {-glucan } \\
{\left[\mathrm{g} / 100 \mathrm{~g}_{\text {d.w. }} \text { prepara- }\right.} \\
\text { tion] }\end{array}$ & $\begin{array}{l}\text { Protein } \\
{\left[\mathrm{g} / 100 \mathrm{~g}_{\text {d.w. }}\right.} \\
\text { preparation] }\end{array}$ & $\begin{array}{l}\text { Lipids } \\
{\left[\mathrm{mg} / 100 \mathrm{~g}_{\text {d.w. }}\right.} \\
\text { preparation] }\end{array}$ & $\begin{array}{l}\text { Production } \\
\text { effiency } \\
{[\%]}\end{array}$ \\
\hline $\mathrm{CW}$ & $73.4 \pm 2.2 \mathrm{~b}$ & $62.6 \pm 0.8 \mathrm{~b}(85.3 \%)$ & $16.4 \pm 1.4 \mathrm{a}$ & $284.6 \pm 31.2 \mathrm{a}$ & - \\
$\beta-\mathrm{G}-1$ & $88.0 \pm 1.0 \mathrm{a}$ & $81.8 \pm 0.2 \mathrm{a}(93.0 \%)^{*}$ & $7.0 \pm 0.8 \mathrm{~b}$ & $134.6 \pm 20.4 \mathrm{~b}$ & $48.9 \pm 0.7 \mathrm{a}$ \\
$\beta-\mathrm{G}-2$ & $86.6 \pm 2.4 \mathrm{a}$ & $82.0 \pm 0.4 \mathrm{a}(94.7 \%)$ & $5.8 \pm 0.2 \mathrm{c}$ & $68.4 \pm 3.8 \mathrm{c}$ & $69.6 \pm 1.4 \mathrm{~b}$ \\
\hline
\end{tabular}

*Percentage share in total sugars

$C W$ cell wall preparation, $\beta-G-1 \beta(1,3) /(1,6)$-glucan preparation purified by method $1, \beta-G-2 \beta(1,3) /$ $(1,6)$-glucan preparation purified by method 2

${ }^{\mathrm{a}, \mathrm{b}, \mathrm{c}}$ Mean values in columns marked with the same letters do not differ significantly, Tukey's test, $\alpha=0.05$ from dissolution of those ingredients at the stage of repeated rinsing of cell wall specimens with ethanol after the procedure of cells disintegration. Freimund et al. [22] noted high efficiency of lipids extraction from yeast cell walls using ethanol. The lipid content in obtained preparations turned out to be definitely lower as compared to data presented in corresponding literature [22, 41, 42, 51].

It is worth to underline that the content of total sugars, proteins and $\beta$-glucan in produced cell wall preparations of C. utilis was similar to their concentration in commercial preparations of purified $\beta$-glucan of $S$. cerevisiae origin studied by Thammakiti et al. [51] and Suphantharika et al. [52]. That proves high efficiency of the process applied for yeast cells disintegration. Furthermore, the culture medium based on the waste DPJW with glycerol used for $C$. utilis cultivation promotes the biosynthesis of $\beta(1,3) /(1,6)$-glucan [13], which explains significantly higher content of that polysaccharide in unpurified cell wall preparations as compared to data available in literature [51-53].

\section{Purified $\beta$-Glucan Preparations}

The first method applied for $\beta$-glucan isolation from the cell walls of studied $C$. utilis yeast species was based on alkaline extraction of that polysaccharide and subsequent moderate acid hydrolysis and hot-water extraction by autoclaving of the material. Alkali treatment of yeast cell walls results in destruction of the spatial organization of the wall and releasing of its structural ingredients [48]. Šandula et al. [49] indicated that $\beta(1,3) /(1,6)$-glucan, isolated from yeast cells through alkaline extraction, still contains substantial quantities of contaminants, mainly mannan, proteins, phospholipids, $\alpha$-glucan as well as amorphous $\beta(1,6)$-glucan stuck in the net of $\beta(1,3)$-glucan fibrilles. Application of moderate acid extraction, for instance using acetic acid, allows to reduce the content of alkali insoluble $\beta(1,6)$-glucan fraction which is sensitive to acetolysis. That process, however, could brings about losses of $\beta(1,3)$-glucan [2, 49]. The subsequent stage of purification of $\beta$-glucan preparation, based on autoclaving of samples suspended in water or buffer, contributed to additional removal of water soluble impurities.
Purification of studied cell wall preparations through the alkaline-acid procedure caused the total content of sugars to rise from approximately 73 to $88 \mathrm{~g} / 100 \mathrm{~g}_{\mathrm{d} . \mathrm{w}}$. of the preparation while $\beta(1,3) /(1,6)$-glucan concentration increased to approximately $82 \mathrm{~g} / 100 \mathrm{~g}_{\mathrm{d} . \mathrm{w}^{*}}$ (about $93 \%$ of total sugars) Table 3. Discussed purification procedure provided for more than double reduction of proteins content in the preparations, finally reducing the concentration from 16 to $7 \mathrm{~g} / 100$ $\mathrm{g}_{\mathrm{d} . \mathrm{w}}$. of $\beta$-glucan preparation. However, proteins concentration was calculated on the basis of total nitrogen content in investigated preparations. The assumption was made that all nitrogen comes from protein fraction while in yeast cell wall preparation the chitin is present and impurities with nucleic acids are also possible. It could be the reason of unpreciseness between results of spectral IR analysis and chemical investigation of protein content in studied preparations.

The content of lipids was about $0.1 \%$ of dry substance of the purified $\beta$-glucan preparation obtained using discussed method of isolation.

Zechner-Krpan et al. [2] noticed lower protein content in $S$. cerevisiae yeast $\beta$-glucan preparations isolated by means of the alkaline-acid extraction connected with hot water extraction by autoclaving. However, the processes of alkaline and hot-water extractions, as carried out by the authors, lasted longer ( 2 and 1,5 $\mathrm{h}$ respectively), as compared to the procedure applied in our study ( $1 \mathrm{~h}$ each).

Production efficiency of purified $\beta$-glucan preparations obtained by alkaline-acid extraction coupled with hotextraction by autoclaving (method 1) approximated to $49 \%$ in relation to the quantity of cell wall preparations used for purification. That commonly used procedure of $\beta$-glucan isolation provides for efficient saponification of esterified lipids and removal of proteins covalently bound with mannan in the cell wall structure, however, it contributes to degradation and substantial losses of isolated polysaccharides [2, 41, 42, 49].

The second method applied in this study for isolation of $\beta(1,3) /(1,6)$-glucan from $C$. utilis cell walls preparations was based on solutions proposed by Freimund et al. [22] and Magnani et al. [42]. Firstly, the extraction of yeast cell walls components soluble in water at the temperature above 
$100{ }^{\circ} \mathrm{C}$ was carried out. Application of hot extraction within the process of yeast $\beta$-glucan purification provides the structure of yeast cell walls more susceptible to further stages of purification. The next step of $\beta$-glucan isolation was based on lipids solubilization using isopropyl alcohol followed by enzymatic digestion of proteins present in cell wall preparations. Kath and Kulicke [4] and Liu et al. [41] underlined that enzymatic deproteinization of cell wall preparations requires lipids to be removed beforehand. Fats, being bound with proteins in the structure of yeast cell walls, protect the latter ones from the impact of lytic enzyme.

The discussed method of $\beta$-glucan separation (method 2 ) allowed to produce purified $\beta$-glucan preparation with definitely higher efficiency (approx. 70\%) as compared to alkaline-acid procedure (Table 3 ). Those $\beta$-glucan preparations were characterised by the total sugar and $\beta(1,3) /$ $(1,6)$-glucan content similar to stated in preparations produced by the method 1 . These were $85 \mathrm{~g}$ and approx. $82 \mathrm{~g}$ per $100 \mathrm{~g}_{\text {d.w }}$. of purified preparation, respectively. In such a purified material, $\beta$-glucan accounted for almost $95 \%$ of total sugars. The content of proteins was approx. $5.8 \mathrm{~g} / 100 \mathrm{~g}_{\text {d.w. }}$. of the preparation. The higher efficiency of protein removal by similar method of purification presented in literature [22, $41,42,54]$ could result from a few times longer process of hot extraction (4-5 h), possible higher hydrolytic activity as well as selectivity of applied proteolytic preparations and the characteristics of material used for glucan isolation. Besides, Magnani et al. [42], after mannoprotein extraction with hot water, applied the process of sonication that cause the polymeric structure of yeast walls to be loosened improving the efficiency of impurities extraction from the structure of $\beta(1,3)$-glucan matrix [42, 49]. Šandula et al. [49] applied ultrasonication to yeast cell walls after the stage of acid extraction. In consequence, the percentage share of $\beta$-glucan in purified preparations was around $15 \%$ higher.

The level of contamination of discussed $\beta$-glucan preparations with lipid fraction (Table 3) was approx. $0.06 \%$ being similar or even lower than described for preparations referred in literature [22, 41, 42, 51]. Liu et al. [41] and Magnani et al. [42] used isopropanol to effectively delipidate $S$. cerevisiae yeast wall preparations to the final content about $0.1 \%$ and $0.2 \%$, respectively.

In purified $\beta$-glucan preparations the presence of oleic acid, stearic acid and palmitic acid were defined whereas in the cell wall preparations the content of 15 fatty acids was analyzed but the three mentioned above constituted about $83 \%$ of evaluated lipid fraction (Table 4). Making a comparison of the content of respective fatty acids in cell wall preparations and $\beta$-glucan preparations it was stated that palmitic acid was the least susceptible to extraction regardless of the purification method. Extraction of lipids using isopropanol provided for removal of approximately $77 \%$ of stearic acid, $74 \%$ of oleic acid and $57 \%$ of palmitic acid.
Table 4 Fatty acids composition and contents is studied cell wall and $\beta$-glucan preparations in relation to purification method

\begin{tabular}{|c|c|c|c|}
\hline Fatty acid & $\begin{array}{l}\mathrm{CW} \\
{\left[\mathrm{mg} / 100 \mathrm{~g}_{\text {d.w. }} \cdot \mathrm{p}\right.}\end{array}$ & $\begin{array}{l}\beta-\mathrm{G}-1 \\
\text { paration] }\end{array}$ & $\beta-\mathrm{G}-2$ \\
\hline C8:0 & $2.4 \pm 0.5$ & nd & nd \\
\hline C10:0 & $1.0 \pm 0.5$ & nd & nd \\
\hline C12:0 & $2.3 \pm 0.3$ & nd & nd \\
\hline $\mathrm{C} 14: 0$ & $1.4 \pm 0.5$ & nd & nd \\
\hline C16:0 & $54.7 \pm 5.3 \mathrm{a}$ & $\begin{array}{l}36.9 \pm 4.5(32.5 \%) \\
\mathrm{b}\end{array}$ & $\begin{array}{l}23.6 \pm 1.1 \\
(56.9 \%) \\
\mathrm{c}\end{array}$ \\
\hline $\mathrm{C} 16: 1$ cis 7 & $2.7 \pm 0.2$ & nd & nd \\
\hline $\mathrm{C} 17: 0$ & $7.8 \pm 0.8$ & $\operatorname{tr}$ & $\operatorname{tr}$ \\
\hline $\mathrm{C} 17: 1$ cis 10 & $2.0 \pm 0.1$ & nd & nd \\
\hline C18:0 & $72.3 \pm 9.0 \mathrm{a}$ & $\begin{array}{l}38.3 \pm 6.6(47.0 \%) \\
\mathrm{b}\end{array}$ & $\begin{array}{l}16.7 \pm 0.3 \\
(76.9 \%) \\
\mathrm{c}\end{array}$ \\
\hline C18:1 cis 9 & $109.9 \pm 10.4 a$ & $\begin{array}{l}59.5 \pm 9.3(45.9 \%) \\
\mathrm{b}\end{array}$ & $\begin{array}{l}28.1 \pm 2.4 \\
(74.4 \%) \\
\mathrm{c}\end{array}$ \\
\hline $\mathrm{C} 18: 2$ cis 9,12 & $3.9 \pm 0.3$ & nd & nd \\
\hline $\mathrm{C} 18: 3$ cis $9,12,15$ & $3.2 \pm 0.3$ & nd & nd \\
\hline $\mathrm{C} 20: 2$ cis 11,14 & $8.4 \pm 0.6$ & $\operatorname{tr}$ & $\operatorname{tr}$ \\
\hline $\mathrm{C} 22: 0$ & $2.0 \pm 0.2$ & nd & nd \\
\hline $\mathrm{C} 24: 0$ & $11.1 \pm 1.9$ & $\operatorname{tr}$ & $\operatorname{tr}$ \\
\hline
\end{tabular}

$C W$ cell wall preparations, $\beta-G-1 \beta(1,3) /(1,6)$-glucan preparation purified by method $1, \beta-G-2 \beta(1,3) /(1,6)$-glucan preparation purified by method 2, $t r$ trace, $n d$ not detected, $C 8: 0$ octanoic acid, $C 10: 0$ decanoic acid, C12:0 dodecanoic acid, C14:0 tetradecanoic acid, C16:0 hexadacanoic acid; C16:1 cis-7-hexadecenoic acid, C17:0 heptadecanoic acid, $C 17: 1$ cis-10-heptadecenoic acid, C18:0 octadecanoic acid, C18:1 cis-9-octadecenoic acid, C18:2 cis-9,12-octadecadienoic acid, C18:3 cis-9,12,15-octadecatrienoic acid, C20:2 cis-11,14-eicosadienoic acid, C22:0 docosanoic acid, C24:0 tetracosanoic acid

*Extraction efficiency in relation to the content in the cell wall preparations

${ }^{a, b, c}$ Mean values in columns marked with the same letters do not differ significantly, Tukey's test, $\alpha=0.05$

Those efficiences were higher as compared to the alkalineacid extraction aided by autoclaving. Apart from lipids in the form of triacyloglycerols in yeast walls there are ergosterol and squalene present both not susceptible to saponification $[22,37]$. The contents of those lipid ingredients were not determined.

The contents of individual fatty acids isolated from nonpurified and purified $S$. cerevisiae cell wall preparations have been presented in few publications only, including the work of Freimund et al. [22]. Cited authors determined four fatty acids (palmitic acid, palmitoleic acid, stearic acid and oleic acid) in yeast $\beta$-glucan preparation. They reported various percentage share of palmitoleic acid and oleic acid in purified cell wall preparations of $S$. cerevisiae yeast, resulted from differences in chemical composition of yeast biomass 
used for $\beta$-glucan isolation and methods of cell walls production.

\section{The Content of Alkali Soluble and Alkali Insoluble Polysaccharide Fractions in Purified $\beta$-Glucan Preparations}

In the structure of $S$. cerevisiae cell wall, three types of $\beta$-glucans are identified. Glucan that is insoluble in alkali, characteristic of high percentage of $\beta(1,3)$-glycosidic bonds and low degree of particle branching (app. 3\%) through $\beta(1,6)$-glycosidic bonds, prevails [4, 49, 55-57]. Another kind of $\beta(1,3)$-glucan is indicative of higher degree of chain branching (8-12\% of $\beta(1,6)$-glycosidic bonds) and solubility in alkali [4]. The polymer containing approximately $80 \%$ of $\beta(1,6)$-glycosidic bonds and with high degree of branching through $\beta(1,3)$ - linkages is soluble in water and acids but insoluble in alkali $[8,58,59]$. However, Klis et al. [8] explain that insolubility of glucans in alkali is determined by the bond with chitin. The content of respective fractions of $\beta$-glucans in yeast wall depends on the yeast strain, growth phase and cultivation conditions $[5,55,60]$. Biological activity is mainly attributed to the water and alkali insoluble fraction of yeast $\beta(1,3) /(1,6)$-glucan [60], however, Ha et al. [55] indicate such activity in relation to the fraction soluble in alkali also.

Obtained $\beta$-glucan preparations, independently on purification method, were characteristic of comparable content of alkali insoluble polysaccharides fraction (approx. $67-69 \%)$. Alkali insoluble $\beta(1,3)$-glucan was stated at the concentration approx. $36 \%$ (Table 5). The $\beta$-glucan preparation isolated by method 2 was slightly more contaminated with polysaccharides soluble in alkali, containing lower amount of alkali-insoluble $\beta(1,6)$-glucan at the same time. In those preparations a higher ratio of $\beta(1,3)$ to $\beta(1,6)$-glucan content was stated. Cell wall proteins are mainly cross-linked with the fibrillar structure of $\beta(1,3)$ glucan via $\beta(1,6)$-glucan molecules in yeast cell wall. Kollár et al. [61] and Ha et al. [55] stated that bonds occurring between mannoproteins and $\beta(1,6)$-glucan play the crucial role in organization of the structure of yeast wall. Within the framework of yeast cell wall structural compounds, chitin is strongly associated with $\beta(1,6)$-glucan. Consequently the lower contamination degree of preparations purified by the method 2 with $\beta(1,6)$-glucan could result in reduction of $\mathrm{N}$-acetylglucosamine concentration, what is in agreement with FT-IR analysis. Probably, enzymatic protein hydrolysis facilitated the release of $\beta(1,6)$-glucan which is soluble in water [4,6]. Moreover, in the case of both studied preparations, the content of $\beta(1,6)$-glucan may be overestimated due to possible glycogen contamination that is hard to be removed from yeast cell wall preparations [62]. At the same time, the presence of branching through $\beta(1,6)$-glycosidic bonds in $\beta(1,3)$-glucan could limit the activity of $\beta(1,3)$-glucanase present in zymolyase preparation. Stronger resistance of $\beta(1,3)$-glucan to the activity of laminarinase (endo- $\beta(1,3)$-glucanase) results from blocking of $\beta(1,3)$-glycosidic bonds by branching created through $\beta(1,6)$-glycosidic binding [55].

Data on quantitative analysis of $\beta(1,3)$ - and $\beta(1,6)$ glucans in yeast $\beta$-glucan preparations are rather unique in literature what make the discussion difficult. In the corresponding literature [2], according to the study by other authors [63], $\beta$-glucan non-soluble in alkali is assumed to contain mainly $\beta(1,3)$-glycoside bonds with a slight percentage of $\beta(1,6)$ - ones. However, cited studies refer to the preparations isolated from $S$. cerevisiae yeast cell walls, that is why they do not have to be comparable with obtained from cells of $C$. utilis. $\beta$-Glucan preparations isolated from $C$. utilis were characterized with considerable percentage of $\beta(1,6)$-glycosidic bonds, which suggests a higher degree of polymer particle branching as compared to $S$. cerevisiae yeast glucans. However, the content of $\beta(1,6)$-glucan seems to be dependent on culture aeration rate and impeller rotation speed [10]. Availability of the larger number of free hydroxyl groups in $\beta$-glucan may influence on functional properties of the preparation, for example increasing the efficiency of mycotoxin binding or antioxidant activity. Higher degree of branching may influence the glucan spatial structure that is important for immunostimulation activity of that polysaccharide. The

Table 5 The content of alkali soluble and alkali insoluble polysaccharides in studied $\beta$-glucan preparations in relation to purification method

\begin{tabular}{llllll}
\hline Preparation & $\begin{array}{l}\text { Alkali soluble polysac- } \\
\text { charides }\left[\mathrm{g} / 100 \mathrm{~g}_{\mathrm{d} . \mathrm{w}^{*}}\right. \\
\text { preparation] }\end{array}$ & $\begin{array}{l}\text { Alkali insoluble polysac- } \\
\text { charides [g/100 } \mathrm{g}_{\mathrm{d} . \mathrm{w}^{*}} \\
\text { preparation] }\end{array}$ & $\begin{array}{l}\beta(1,3) \text {-glucan insoluble } \\
\text { in alkali }\left[\mathrm{g} / 100 \mathrm{~g}_{\mathrm{d} . \mathrm{w}^{*}}\right. \\
\text { preparation] }\end{array}$ & $\begin{array}{l}\beta(1,6) \text {-glucan insoluble } \\
\text { in alkali }\left[\mathrm{g} / 100 \mathrm{~g}_{\mathrm{d} . \mathrm{w}^{*}}\right. \\
\text { preparation] }\end{array}$ & $\begin{array}{l}\text { The ratio of } \beta(1,3)-\text { to } \\
\beta(1,6) \text {-glucan content }\end{array}$ \\
\hline$\beta-\mathrm{G}-1$ & $16.7 \pm 1.2 \mathrm{a}$ & $68.7 \pm 6.2 \mathrm{a}(80.4 \%)^{*}$ & $35.5 \pm 5.9 \mathrm{a}(50.9 \%)^{* *}$ & $34.2 \pm 3.5 \mathrm{a}(49.1)^{* *}$ & 1.04 \\
$\beta-\mathrm{G}-2$ & $18.5 \pm 2.0 \mathrm{~b}$ & $66.5 \pm 5.1 \mathrm{a}(78.3 \%)^{*}$ & $36.3 \pm 5.6 \mathrm{a}(55.1 \%)^{* *}$ & $29.7 \pm 3.7 \mathrm{~b}(44.9 \%)^{* *}$ & 1.23 \\
\hline
\end{tabular}

*Percentage in total content of alkali soluble and insoluble polysaccharides

**The percentage in the total content of $\beta$-glucans insoluble in alkali

$\beta$ - $G-1 \beta(1,3) /(1,6)$-glucan preparation purified by method $1, \beta-G-2 \beta(1,3) /(1,6)$-glucan preparation purified by method 2

${ }^{\mathrm{a}, \mathrm{b}, \mathrm{c}}$ Mean values in columns marked with the same letters do not differ significantly, Tukey's test, $\alpha=0.05$ 


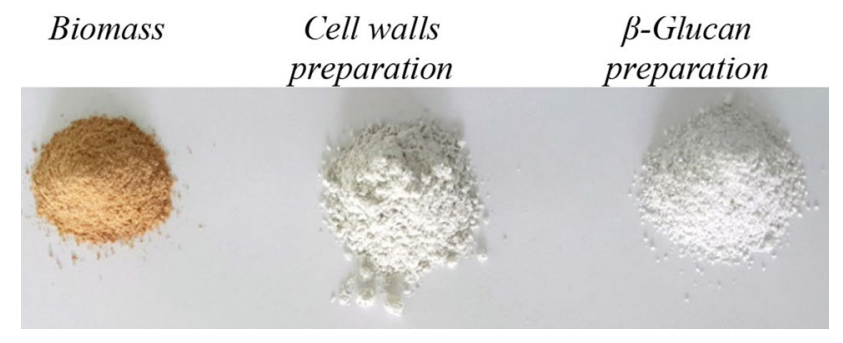

Fig. 5 Example image of preparations of C. utilis ATCC 9950 biomass, cell walls and purified $\beta$-glucan

exact chemical structure of isolated $\beta$-glucan molecule and its functional properties will be the subject of our further studies.

Figure 5 presents exemplary photographs of examined preparations of cell walls and purified $\beta$-glucan but also biomass of tested Candida utilis. Cell walls and purified $\beta$-glucan were characterized by a cream colour, whereas freeze-dried biomass was brick-brown. The powders of cell wall preparations had a flour-like structure and showed a tendency to form lumps, while the preparations of purified $\beta$-glucan were looser and showed greater adhesiveness.

\section{Conclusions}

Candida utilis biomass cultivated on industrial potato waste water is efficient system to produce purified $\beta$-glucan. Infrared spectra of $\beta(1,3) /(1,6)$-glucan preparation were highly similar to $\beta$-glucan reference spectra. The content of $\beta(1,3) /(1,6)$-glucan was in both methods app. $82 \%$ of total preparation mass which makes $93-95 \%$ of total sugars mass in tested preparations. The ratio of alkali insoluble $\beta(1,3)$ - to $\beta(1,6)$-glucan was 1.23 and 1.04 for methods 2 and 1 , respectively. The production efficiency for method 2 was $70 \%$ while $49 \%$ only for the method 1 .

Functional properties of isolated $\beta$-glucan preparation of $C$. utilis origin are the objective for further studies.

Funding This work was financially supported by the Polish Ministry of Science and Higher Education as a part of the resources allocated for science in 2015 to 2016.

\section{Compliance with Ethics Standards}

Conflict of interest The authors declare no conflict of interest.

Human and Animal Rights This article does not contain any studies with human or animal subjects.
Open Access This article is distributed under the terms of the Creative Commons Attribution 4.0 International License (http://creativeco mmons.org/licenses/by/4.0/), which permits unrestricted use, distribution, and reproduction in any medium, provided you give appropriate credit to the original author(s) and the source, provide a link to the Creative Commons license, and indicate if changes were made.

\section{References}

1. Batbayar, S., Lee, D.H., Kim, H.W.: Immunomodulation of fungal $\beta$-glucan in host defense signaling by dectin-1. Biomol. Ther. 20(5), 433-445 (2012)

2. Zechner-Krpan, V., Petravić-Tominac, V., Gospodarić, I., Daković, S.L., Filipović-Grčić, S.: J.: Characterization of $\beta$-glucans isolated from brewer's yeast and dried by different methods. Food Technol. Biotechnol. 48(2), 189-197 (2010)

3. Rahar, S., Swami, G., Nagpal, N., Singh, G.S.: Preparation, characterization, and biological properties of $\beta$-glucans. J. Adv. Pharm. Technol. Res. 2(2), 94-103 (2011)

4. Kath, F., Kulicke, W.M.: Mild enzymatic isolation of mannan and glucan from yeast Saccharomyces cerevisiae. Die Angew. Macromol. Chem. 268, 59-68 (1999)

5. Nguyen, T.H., Fleet, G.H., Rogers, P.L.: Composition of the cell walls of several yeast species. Appl. Microbiol. Biotechnol. 50(2), 206-212 (1998)

6. Smits, G.J., Van den Ende, H., Klis, F.M.: Differential regulation of cell wall biogenesis during growth and development in yeast. Microbiology 147, 781-794 (2001)

7. Lesage, G., Sdicu, A.M., Ménard, P., Shapiro, J., Hussein, S., Bussey, H.: Analysis of beta-1,3-glucan assembly in Saccharomyces cerevisiae using a synthetic interaction network and altered sensitivity to caspofungin. Genetics 167(1), 35-49 (2004)

8. Klis, F.M., Mol, P., Hellingwerf, K., Brul, S.: Dynamics of cell wall structure in Saccharomyces cerevisiae. FEMS. Microbiol. Rev. 26(3), 239-256 (2002)

9. Bzducha-Wróbel, A., Błażejak, St, Kieliszek, M., Pobiega, K., Falana, K., Janowicz, M.: Modification of the cell wall structure of Saccharomyces cerevisiae strains during cultivation on waste potato juice water and glycerol towards biosynthesis of functional polysaccharides. J. Biotechnol. 281, 1-10 (2018)

10. Bzducha-Wróbel, A., Pobiega, K., Błażejak, St, Kieliszek, M.: The scale-up cultivation of Candida utilis in waste potato juice water with glycerol affects biomass and $\beta(1,3) /(1,6)$-glucan characteristic and yield. Appl. Microbiol. Biotechnol. 102, 9131-9145 (2018)

11. Kopecká, M.: Yeast and fungal cell-wall polysaccharides can selfassemble in vitro into an ultrastructure resembling in vivo yeast cell walls. J. Electron Microsc. 62(3), 327-339 (2013)

12. Lowman, D.W., Ferguson, D.A. Jr., Williams, D.L.: Structural characterization of $(1 \rightarrow 3)-\beta$-D-glucans isolated from blastospore and hyphal forms of Candida albicans. Carbohydr. Res. 338, 1491-1496 (2003)

13. Bzducha-Wróbel, A., Błażejak, S., Molenda, M., Reczek, L.: Biosynthesis of $\beta(1,3) /(1,6)$-glucans of cell wall of the yeast Candida utilis ATCC 9950 strains in the culture media supplemented with deproteinated potato juice water and glycerol. Eur. Food Res. Technol. 240, 1023-1034 (2015)

14. Dzwonkowski, W.: Perspektywy rynku skrobi i produkcji ziemniaków skrobiowych w kontekście zmian wspólnej polityki rolnej. Biul. Inst. Hod. Aklim. Rośl. 265, 99-108 (2012)

15. Gientka, I., Aleksandrzak-Piekarczyk, T., Bzducha-Wróbel, A., Synowiec, A., Błażejak, S.: Deproteinated potato wastewater as a sustainable nitrogen source in Trichosporon domesticum yeast lipids biosynthesis: a concept of valorization of wastewater from 
starch industry. Potato Res. https://doi.org/10.1007/s11540-0189408-x (2019)

16. Kowalczewski, P., Celka, K., Białas, W., Lewandowicz, G.: Antioxidant activity of potato juice. Acta Sci. Pol. Technol. Aliment 11(2), 175-181 (2012)

17. Potato starch market: global industry trends, share, size, growth, opportunity and forecast 2018-2023. Research and Markets. The world's largest market research store. https://www.resea rchandmarkets.com/reports/4535068/potato-starch-marke t-global-industry-trends Accessed 30 Jan 2019

18. Kujawska, M., Olejnik, A., Lewandowicz, G., Kowalczewski, P., Forjasz, R., Jodynis-Liebert, J.: Spray-dried potato juice as a potential functional food component with gastrointestinal protective effects. Nutrients 10(2), 259, https://doi.org/10.3390/ nu10020259 (2018)

19. Baranowska, H.M., Masewicz, Ł, Kowalczewski, P., Grażyna Lewandowicz, G., Piątek, M., Kubiak, P.: Water properties in pâtés enriched with potato juice. Eur. Food Res. Technol. 244, 387-393 (2017)

20. Kowalczewski, P., Lewandowicz, G., KrzywdzińskaBartkowiak, M., Piątek, M., Baranowska, H.M., Białas, W., Jeziorna, M., Kubiak, P.: Finely comminuted frankfurters fortified with potato juice-quality and structure. J. Food Eng. 167, 183-188 (2015)

21. Kowalczewski, P., Lewandowicz, G., Makowska, A., Knoll, I., Błaszczak, W., Białas, W., Kubiak, P.: Pasta fortified with potato juice: structure, quality, and consumer acceptance. J. Food Sci. 80, S1377-S1382 (2015)

22. Freimund, S., Sauter, M., Käppeli, O., Dutler, H.: A new nondegrading isolation process for 1,3- $\beta$-d-glucan of high purity from baker's yeast. Saccharomyces cerevisiae. Carbohydr. Polym. 54(2), 159-171 (2003)

23. Schäppi, M., Deffert, C., Fiette, L., Gavazzi, G., Herrmann, F., Belli, D., Krause, K.H.: Branched fungal $\beta$-glucans causes hyperinflammantation and necrosis in phagocyte NADPH oxidase-deficient mice. J. Pathol. 214, 434-444 (2008)

24. Bacha, U., Nasir, M., Iqbal, S., Anjum, A.A.: Nutraceutical, anti-inflammatory, and Immune modulatory effects of $\beta$-glucan isolated from yeast. Biomed. Res. Int. Article ID 8972678, p 14 (2017)

25. Samuelsen, A.B., Schrezenmeir, J., Knutsen, S.H.: Effects of orally administered yeast-derived beta-glucans: a review. Mol. Nutr. Food Res. 58(1), 183-193 (2014)

26. Stier, H., Ebbeskotte, V., Gruenwald, J.: Immune-modulatory effect of dietary yeast beta-1,3/1,6-D-glucan. Nutr. J. 13(1), 38 (2014)

27. Zhu, F., Du, B., Xu, B.: A critical review on production and industrial applications of beta-glucans. Food Hydrocoll 52, 275-288 (2016)

28. Baert, K., De Geest, B.G., De Greve, H., Cox, E., Devriendt, B.: Duality of $\beta$-glucan microparticles: antigen carrier and immunostimulants. Int. J. Nanomed. 11, 2463-2469 (2016)

29. Tang, Q., Huang, G., Zhao, F., Zhou, L., Huang, S., Li, H.: The antioxidant activities of six $(1 \rightarrow 3)$ - $\beta$-D-glucan derivatives prepared from yeast cell wall. Int. J. Biol. Macromol. 98, 216-221 (2017)

30. Liu, Y., Huang, G., Lv, M.: Extraction, characterization and antioxidant activities of mannan from yeast cell wall. Int. J. Biol. Macromol. 118, 952-956 (2018)

31. Tang, Q., Huang, G.: Progress in polysaccharide derivatization and properties. Mini Rev. Med. Chem. 16(15), 1244-1257 (2016)

32. Jard, G., Libo, T., Mathieu, F., Guyonvarc, A., Lebrihi, A.: Review of mycotoxin reduction in food and feed: from prevention in the field to detoxification by adsorption or transformation. Food Addit. Contam. Part A 28(11), 1590-1609 (2011)
33. Commission Implementing Decision of 24: November 2011 authorising the placing on the market of yeast beta-glucans as anovel food ingredient under Regulation (EC) No 258/97 of the European Parliament and of the Council

34. Novák, M., Synytsya, A., Gedeon, O., Slepička, P., Procházka, V., Synytsya, A., Blahovec, J., Hejlová, A., Čopíková, J.: Yeast $\beta(1,3),(1,6)$-D-glucan films: preparation and characterization of some structural and physical properties. Carbohydr. Polym. 87, 2496-2504 (2012)

35. Satrapai, S., Suphantharika, M.: Influence of spent brewer's yeast $\beta$-gelatinization and retogradation of rice starch. Carbohyd. Polym. 67, 500-510 (2007)

36. Worrasinchai, S., Suphantharika, M., Pinjai, S., Jamnong, P.: $\beta$-Glucan prepared from spent brewer's yeast as a fat replacer in mayonnaise. Food Hydrocoll. 20(1), 68-78 (2006)

37. Borchani, Ch, Fonteyn, F., Jamin, G., Paquot, M., Blecker, Ch: Enzymatic process for the fractionation of baker's yeast cell wall. Food Chem. 163, 108-113 (2014)

38. Dalonso, N., Goldman, G.H., Gern, R.M.: $\beta-(1 \rightarrow 3),(1 \rightarrow 6)-$ Glucans: medicinal activities, characterisation, biosynthesis and new horizons. Appl. Microbiol. Biotechnol. 99(19), 7893-7906 (2015)

39. Varelas, V., Liouni, M., Calokerinos, A.C., Nerantzis, E.T.: An evaluation study of different methods for the production of $\beta$-Dglucan from yeast biomass. Drug Test Anal. 8, 46-55 (2016)

40. Liepins, J., Kovačova, E., Shvirksts, K., Grube, M., Rapoport, A., Kogan, G.: Drying enhances immunoactivity of spent brewer's yeast cell wall $\beta$-D-glucans. J. Biotechnol. 206, 12-16 (2015)

41. Liu, X.Y., Wang, Q., Cui, S.W., Liu, H.Z.: A new isolation method of $\beta$-D-glucans from spent yeast Saccharomyces cerevisiae. Food Hydrocoll. 22, 239-247 (2008)

42. Magnani, M., Calliari, C.M., de Macedo, J.F.C., Mori, M.P., de Syllos Cólus, I.M., Casto-Gomez, R.J.H.: Optimized methodology for extraction of $(1 \rightarrow 3)(1 \rightarrow 6)-\beta$-D-glucan from from $S a c$ charomyces cerevisiae and in vitro evaluation of the cytotoxicity and genotoxicity of the corresponding carboxymethyl derivative. Carbohydr. Polym. 78(4), 658-665 (2009)

43. Charpentier, C., Van Long, T.N., Bonaly, R., Feuillat, M.: Alteration of cell wall structure in Saccharomyces cerevisiae and Sacharomyces bayanus during autolysis. Appl. Microbiol. Biotechnol. 24, 405-413 (1986)

44. Giovani, G., Canuti, V., Rosi, I.: Effect of yeast strain and fermentation conditions on the release of cell wall polysaccharides. Int. J. Food Microbiol. 137, 303-307 (2010)

45. Pengkumsri, N., Sivamaruthi, B.S., Sirilun, S., Peerajan, S., Kesika, P., Chaiyasut, K., Chaiyasut, Ch: Extraction of $\beta$-glucan from Saccharomyces cerevisiae: comparison of different extraction methods and in vivo assessment of immunomodulatory effect in mice. Food Sci. Technol. 37(1), 124-130 (2017)

46. Bzducha-Wróbel, A., Błażejak, S., Kawarska, A., StasiakRóżańska, L., Gientka, I., Majewska, E.: Evaluation of the efficiency of different disruption methods on yeast cell wall preparation for $\beta$-glucan isolation. Molecules 19(12), 20941-20961 (2014)

47. Kieliszek, M., Błażejak, S., Bzducha-Wróbel, A., Kot, A.M.: Correction: effect of selenium on lipid and amino acid metabolism in yeast cells. Biol. Trace Elem. Res. 187, 328-328 (2019)

48. Bzducha-Wróbel, A., Kieliszek, M., Błażejak, S.: Chemical composition of the cell wall of probiotic and brewer's yeast in response to cultivation medium with glycerol as a carbon source. Eur. Food Res. Technol. 237, 489-499 (2013)

49. Šandula, J., Kogan, G., Kačuráková, M., Machová, E.: Microbial $(1 \rightarrow 3)$ - $\beta$-D-glucans, their preparation, physico-chemical characterization and immunomodulatory activity. Carbohyd. Polym. 38, 247-253 (1999) 
50. Zlatković, D., Jakovljević, D., Zeković, Đ, Vrvić, M.M.: A glucan from active dry baker's yeast (Saccharomyces cerevisiae): a chemical and enzymatic investigation of the structure. J. Serb. Chem. Soc. 68(11), 805-809 (2003)

51. Thammakiti, S., Suphantharika, M., Phaesuwan, T., Verduyn, C.: Preparation of spent brewer's yeast $\beta$-glucans for potential application in the food industry. Int. J. Food Sci. Technol. 39, 21-29 (2004)

52. Suphantharika, M., Khunrae, P., Thanardkit, P., Verduyn, C.: Preparation of spent brewer's yeast $\beta$-glucans with a potential application as an immunostimulant for black tiger shrimp Penaeusmonodon. Bioresour. Technol. 88, 55-56 (2003)

53. Jaehrig, S.C., Rohn, S., Kroh, L.W., Wildenauer, F.X., Lisdat, F., Fleischer, L.G., Kurz, T.: Antioxidative activity of $(1 \rightarrow 3),(1 \rightarrow 6)-\beta$-D-glucan from Saccharomyces cerevisiae grown on different media. LWT 41, 868-877 (2008)

54. Da Silva Araújo, V.B., de Melo, A.N.F., Costa, G.A., CastroGomez, R.H., Madruga, M.S., de Souza, E.L., Magnani, M.: Followed extraction of $\beta$-glucan and mannoprotein from spent brewer's yeast (Saccharomyces uvarum) and application of the obtained mannoprotein as a stabilizer in mayonnaise. Innov. Food Sci. Emerg. Technol. 23, 164-170 (2014)

55. Ha, C.H., Lim, K.H., Kim, Y.T., Lim, S.T., Kim, C.W., Chang, H.I.: Analysis of alkali-soluble glucan produced by Saccharomyces cerevisiae wild-type and mutants. Appl. Microbiol. Biotechnol. 58, 370-377 (2002)

56. Huang, G., Li, J.: Efficient preparation of alkali-insoluble $(1 \rightarrow 3)$ - $\beta$-D-glucan. Int. J. Food Sci. Nutr. 63(2), 184-186 (2012)
57. Mantovani, M.S., Bellini, M.F., Angeli, J.P., Oliveira, R.J., Silva, A.F., Ribeiro, L.R.: Beta-Glucans in promoting health: prevention against mutation and cancer. Mutat. Res. 658(3), 154-161 (2008)

58. Bowman, S.M., Free, S.J.: The structure and synthesis of the fungal cell wall. BioEssays 28, 799-808 (2006)

59. Fleet, G.H., Manners, A.D.J.: Isolation and composition of an alkali-soluble glucan from cell walls of Saccharomyces cerevisiae. J. Gen. Microbiol. 94(1), 180-192 (1976)

60. Hunter, K.W., Gult, R.A., Berner, M.D.: Preparation of microparticulate $\beta$-glucan from Saccharomyces cerevisiae for use in immune potentiation. Lett. Appl. Microbiol. 35, 267-271 (2002)

61. Kollaár, R., Reinhold, B.B., Petráková, E., Yeh, H.J.C., Ashwell, G., Drgonová, J., Kapteyn, J.C., Klis, F.M., Cabib, E.: Architecture of the yeast cell wall. $\beta(1,6)$-glucan interconnects $\beta(1,3)$-glucan, mannoprotein and chitin. J. Biol. Chem. 272(28), 17762-17775 (1997)

62. Kwiatkowski, S., Kwiatkowski, S.E.: Yeast (Saccharomyces cerevisiae) glucan polysaccharides-occurrence, separation and application in food, feed and health industries. InTech 2, 47-70 (2012)

63. Manners, D.J., Masson, A.J., Patterson, J.C.: The structure of a $\beta$-(1,3)-glucan from yeast cell walls. Biochem. J. 135, 19-30 (1973)

Publisher's Note Springer Nature remains neutral with regard to jurisdictional claims in published maps and institutional affiliations.

\section{Affiliations}

\section{Anna Bzducha-Wróbel ${ }^{1}\left[\right.$ Piotr Koczoń $^{2} \cdot$ Stanisław Błażejak ${ }^{1} \cdot$ Jakub Kozera $^{1} \cdot$ Marek Kieliszek $^{1}$}

Anna Bzducha-Wróbel

anna_bzducha_wrobel@sggw.pl

1 Department of Biotechnology, Microbiology and Food Evaluation, Faculty of Food Science, Warsaw University of Life Sciences - SGGW, Nowoursynowska 159c, 02-776 Warsaw, Poland
2 Department of Chemistry, Faculty of Food Science, Warsaw University of Life Sciences - SGGW, Nowoursynowska 159c, 02-776 Warsaw, Poland 